\title{
Molluscan fauna in the freshwater tidal area of the River Minho estuary, NW of Iberian Peninsula
}

\author{
R. Sousa $1,2 *$, L. Guilhermino ${ }^{1,2}$, C. Antunes ${ }^{1}$ \\ 1 CIIMAR, Centro Interdisciplinar de Investigação Marinha e Ambiental, Rua dos Bragas, 4050-123 Porto, Portugal. \\ 2 ICBAS, Instituto de Ciências Biomédicas de Abel Salazar, Universidade do Porto, Departamento de Estudos de Populações, Laboratório de \\ Ecotoxicologia, Lg. Prof. Abel Salazar 2, 4099-003 Porto, Portugal
}

\begin{abstract}
Ten species of molluscs were identified in the freshwater tidal area of the River Minho estuary. Species richness per site ranged from 1 to 9 . Abundance ranged from 230 to 4130 individuals per $\mathrm{m}^{2}$, with an average of 1412 individuals per $\mathrm{m}^{2}$. Corbicula fluminea (Müller, 1774) presented the highest density, corresponding to $88.7 \%$ of the total specimens gathered, followed by Pisidium amnicum (Müller, 1774) with $5.8 \%$. Biomass ranged from 17.0 to $249.6 \mathrm{~g}_{\text {AFDW m}}{ }^{2}$, with an average of $99.8 \mathrm{~g}$ AFDW m ${ }^{-2}$. C. fluminea was the species dominating the total biomass $(95.4 \%)$, followed by Bithynia tentaculata (Linnaeus, 1758 ) with $1.6 \%$. A multivariate analysis revealed a community with two distinct groups : one group almost or exclusively represented by $C$. fluminea, and another group with a more diverse assemblage.
\end{abstract}

Keywords : River Minho estuary, abundance, biomass, molluscs, diversity, environmental factors.

\section{Introduction}

Ecological boundaries, such as freshwater-estuarine transitional zones, are extremely important for biological and environmental processes since they have high biological diversity and are key areas for chemical and biological interactions (Schiemer \& Zalewski 1992, Attrill et al. 1996, Rundle et al. 1998, Attrill \& Rundle 2002). These transitional areas are regularly subject to several environmental problems including poor land usage policies, reservoir construction, eutrophication processes, chemical pollution, degradation of water quality, dredging and other hydrological regulations (Ysebaert et al. 1998, 2002, 2003). Despite their high biological and ecological importance, little attention has been devoted to the study of these boundary areas. One possible explanation is that estuaries are commonly studied by marine researchers who have, principally, investigated the lower and middle areas of the estuarine ecosystem in connection with the adjacent

\footnotetext{
* Corresponding author : E-mail : ronaldo.sousa@ cimar.org
}

marine system. In addition the interaction between freshwater and estuarine scientists is still relatively low, leading to a lack of cross information that also contributes to a deficit of data in these boundary areas (Attrill et al. 1996, Rundle et al. 1998). Consequently, the development of freshwater tidal faunal databases is fundamental in order to increase the knowledge about the relationship between spatial distribution of benthic species and environmental variables.

Molluscs are one of the most abundant faunal groups in freshwater estuarine tidal areas, being the main food for many species of fish and birds. Furthermore, they are sensitive to human influences and suitable bioindicators organisms in freshwater, estuarine and coastal ecosystems. Additionally, within the estuarine foodwebs, molluscan species perform important ecological functions, being one of the most important primary consumers capable of capturing substantial amounts of suspended materials by filtering water at high rates and thus able to control phytoplankton standing stocks, primary production, water clarity, nutrient cycling and the nature of the food webs (Gerritsen et al. 1994, Nakamura \& Kerciku 2000, Gangnery et al. 2001, Kohata et al. 2003). However, despite their wide use in several 
types of ecological and toxicological studies, very little attention has been devoted to the use of molluscs in monitoring programs of freshwater-estuarine transitional ecosystems.

The aims of this study were to investigate possible relationship between environmental factors and the spatial distribution of the molluscan species, to perform a first estimate of the abundance, biomass and diversity of the molluscan fauna occurring in the freshwater tidal area of the River Minho estuary, and to identify possible key species in the functioning of the ecosystem.

\section{Materials and methods}

\section{Study Area}

The River Minho drains a hydrological basin of $17080 \mathrm{~km}^{2}, 95 \%$ of which being located in Spain and $5 \%$ in Portugal. This river originates in Serra da Mei$\mathrm{ra}$, in the province of Lugo, Spain. It has an extent of $300 \mathrm{~km}(70 \mathrm{~km}$ are located in the Portuguese/Spanish border) draining NNE-SSW into the Atlantic Ocean. Its estuary is located in the NW of Iberian Peninsula and the influence of spring tides extends approximately $40 \mathrm{~km}$ upstream. It has a maximum width of just over $2 \mathrm{~km}$ and is partially mixed, although during the period of high floods it tends to evolve towards a salt wedge estuary (Alves 1996). This estuarine area contains important habitats. However, in the last years this region has been exposed to various impacts due to the drainage of waste from domestic, industrial and agricultural activities; recreational and commercial watercraft activities; fishing activities; dredging works and hydrological regulations. Economically, this is an important estuary for the region, with great preponderance for tourism, fishing and agriculture activities.

\section{Sampling and Data analysis}

In the autumn of 2004, molluscs were sampled along the limnetic area of the River Minho estuary during high tide. Quantitative samples were carried out in 16 sampling stations (Fig. 1) using a Van Veen grab with an area of $500 \mathrm{~cm}^{2}$ and a maximum capacity of $5000 \mathrm{~cm}^{3}$. All the sampling stations were located in

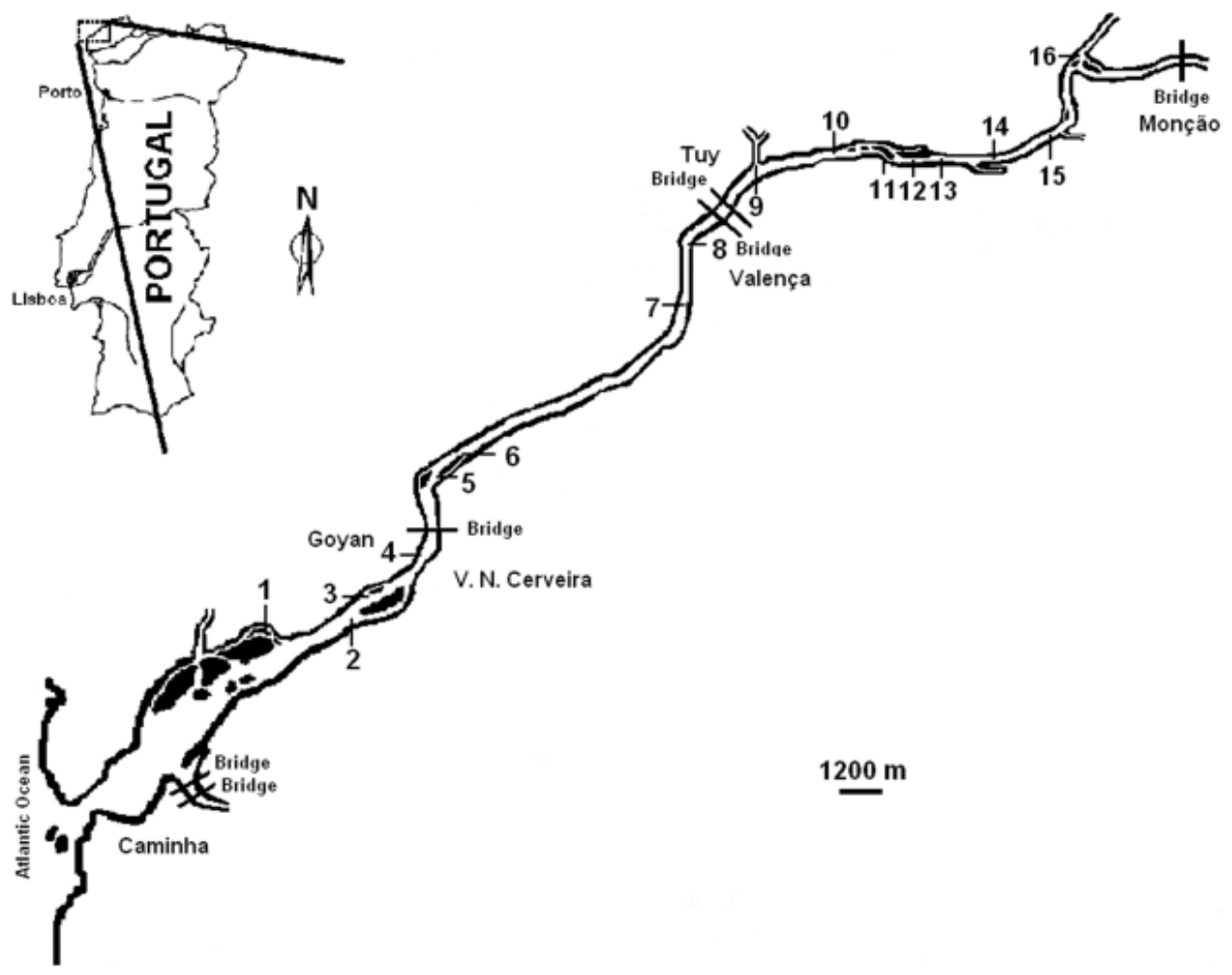

Fig. 1. Map of River Minho estuary, and location of the sixteen sampling sites. 
Table 1. Temperature $\left(\mathrm{T},{ }^{\circ} \mathrm{C}\right)$, conductivity $\left(\mathrm{CND}, \mu \mathrm{S} \mathrm{cm}^{-1}\right)$, total dissolved solids (TDS, $\left.\mathrm{mgl}^{-1}\right)$, redox potential (ORP, $\left.\mathrm{mV}\right)$, salinity $(\mathrm{S}, \mathrm{psu})$, dissolved oxygen (DO, $\left.\mathrm{mgl}^{-1}\right) \mathrm{pH}$, chlorophyll $\left(\mathrm{Chl}, \mu \mathrm{gl}^{-1}\right)$, nitrites $\left(\mathrm{mgl}^{-1}\right)$, nitrates $\left(\mathrm{mgl}^{-1}\right)$, ammonia $\left(\mathrm{mgl}^{-1}\right)$ and phosphates $\left(\mathrm{mgl}^{-1}\right)$ of water column; and organic matter (OM, \%) and silt + clay $(\mathrm{S}+\mathrm{C}, \%)$ of sediment at the sixteen sampling stations. The distance to the ocean (DST, km) at the sixteen sampling stations is also given.

\begin{tabular}{|c|c|c|c|c|c|c|c|c|c|c|c|c|c|c|c|c|}
\hline Abiotic factors & St. 1 & St. 2 & St. 3 & St. 4 & St. 5 & St. 6 & St. 7 & St. 8 & St. 9 & St. 10 & St. 11 & St. 12 & St. 13 & St. 14 & St. 15 & St. 16 \\
\hline $\mathrm{T}\left({ }^{\circ} \mathrm{C}\right)$ & 17.35 & 17.33 & 17.05 & 17 & 17.55 & 17.3 & 17.66 & 17.87 & 17.88 & 17.5 & 17.3 & 16.34 & 16.41 & 16.27 & 16.39 & 15.75 \\
\hline $\operatorname{CND}\left(\mu \mathrm{Scm}^{-1}\right)$ & 479 & 296 & 277 & 134 & 141 & 443 & 88 & 91 & 95 & 74 & 93 & 70 & 69 & 70 & 70 & 65 \\
\hline $\operatorname{TDS}\left(\mathrm{mgl}^{-1}\right)$ & 0.38 & 0.24 & 0.22 & 0.11 & 0.11 & 0.34 & 0.07 & 0.07 & 0.07 & 0.07 & 0.07 & 0.07 & 0.07 & 0.07 & 0.07 & 0.06 \\
\hline ORP (mV) & 202.7 & 193.8 & 195 & 193.4 & 195.2 & 272.8 & 262.4 & 239.8 & 174.8 & 154.4 & 169.5 & 198.1 & 231.2 & 241.1 & 263.3 & 257.4 \\
\hline S (psu) & 0.8 & 0.77 & 0.56 & 0.34 & 0.26 & 0.25 & 0.05 & 0.05 & 0.05 & 0.05 & 0.05 & 0.05 & 0.05 & 0.05 & 0.05 & 0.04 \\
\hline $\mathrm{DO}\left(\mathrm{mgl}^{-1}\right)$ & 10.8 & 11.07 & 10.92 & 10.81 & 9.88 & 8.64 & 9.18 & 9.09 & 9.25 & 10.71 & 10.69 & 10.58 & 10.29 & 9.87 & 9.93 & 9.46 \\
\hline $\mathrm{pH}$ & 8.21 & 8.02 & 7.89 & 7.91 & 7.93 & 7.37 & 7.5 & 7.51 & 7.57 & 7.64 & 7.37 & 7.69 & 7.59 & 7.46 & 7.66 & 7.57 \\
\hline $\mathrm{Chl}\left(\mu \mathrm{gl}^{-1}\right)$ & 5 & 5.2 & 4.9 & 5.3 & 5.1 & 5.2 & 5.6 & 5.3 & 4.8 & 4.3 & 5.6 & 5.48 & 5.39 & 5.29 & 5.36 & 5.09 \\
\hline Nitrites $\left(\mathrm{mgl}^{-1}\right)$ & 0 & 0.01 & 0.01 & 0 & 0.01 & 0 & 0 & 0 & 0.02 & 0.01 & 0.02 & 0.02 & 0.02 & 0.01 & 0.02 & 0.04 \\
\hline Nitrates $\left(\mathbf{m g l}^{-1}\right)$ & 0.8 & 1.04 & 0.6 & 0.52 & 0.63 & 1.14 & 0.94 & 0.78 & 0.96 & 0.81 & 1.02 & 1.12 & 1.08 & 0.64 & 0.84 & 1.22 \\
\hline Ammonia $\left(\mathrm{mgl}^{-1}\right)$ & 0.09 & 0.05 & 0 & 0.04 & 0.03 & 0.15 & 0.05 & 0.05 & 0.18 & 0.04 & 0.13 & 0 & 0 & 0 & 0 & 0 \\
\hline Phosphates (mgl $\mathrm{l}^{-1}$ ) & 0.07 & 0.19 & 0.04 & 0.06 & 0.07 & 0 & 0.13 & 0 & 0.08 & 0 & 0.05 & 0.07 & 0.06 & 0.03 & 0.07 & 0.29 \\
\hline OM $(\%)$ & 1.27 & 10.67 & 0.53 & 0.6 & 0.9 & 2.63 & 2.98 & 2.33 & 8.7 & 10.9 & 10.4 & 13.96 & 0.78 & 0.44 & 1.44 & 0.52 \\
\hline$S+C(\%)$ & 0.86 & 26.26 & 0.06 & 0.28 & 0.49 & 4.82 & 7.22 & 7.22 & 22.03 & 20.53 & 14.56 & 27.55 & 0.25 & 0.01 & 0.31 & 0.08 \\
\hline DST (km) & 8 & 10 & 11 & 14 & 17 & 18 & 25 & 27 & 30 & 32 & 34 & 35 & 36 & 37.5 & 39 & 42 \\
\hline
\end{tabular}

subtidal soft bottoms near the shore.

For each sampling station the following water column information was recorded : temperature, conductivity, total dissolved solids, redox potential, salinity, dissolved oxygen, $\mathrm{pH}$, chlorophyll, nitrites, nitrates, ammonia and phosphates. The information for the first eight environmental factors was obtained in situ, close to the bottom, using a multiparametrical sea gauge YSI 820. Nitrites, nitrates, ammonia and phosphates were analyzed in laboratory by colorimetry. Sediment samples were collected and analysed for granulometry and organic matter content. For granulometry, samples were removed from a replicate and then put into a furnace for 72 hours at $60^{\circ} \mathrm{C}$. Next, a dimensional analysis was performed by sifting with a Ro-Tap agitation, with columns of sieve, according to the dimensional scale of different mesh sizes ( $>2 \mathrm{~mm}$ - gravel; 1 - $2 \mathrm{~mm}$ - very coarse sand; 0.5 - 1mm - coarse sand; 0.25 - 0.5 $\mathrm{mm}$ - medium sand; $0.125-0.25 \mathrm{~mm}$ - fine sand; 0.063 - $0.125 \mathrm{~mm}$ - very fine sand; $<0.063 \mathrm{~mm}-$ silt + clay) and the frequency of each class was expressed as $\%$ of total weight. The quantity of organic matter contained in the sediment was determined, after combusting during 24 hours at $550^{\circ} \mathrm{C}$ in a muffle furnace. Values are expressed in percentage relatively to the weight loss on ignition of each sample analysed.

Biological material was processed through a sieve with a mesh size of $500 \mu \mathrm{m}$ and animals were separated, sorted, fixed in $70 \%$ ethanol and, whenever possible, identified to species level. Faunal biomass was calculated using the Ash Free Dry Weight Method AFDW (Kramer et al. 1994).
An [environmental variable $\mathrm{x}$ sampling station] matrix was analysed using PCA (Principal Components Analysis) for ordination of sampling stations and environmental factors, on the basis that stations ordinated together are more similar, based on the environmental factors measured, than stations ordinated far apart. Ordination by non-metric multidimensional scaling (MDS) based on the Bray-Curtis similarity matrix was used to investigate spatial distribution of molluscan benthic assemblages. These analyses were applied using the PRIMER package (Clarke \& Warwick 2001).

\section{Results}

The physical and chemical parameters are presented in Table 1 (the results of sediment samples present only the estimation of silt + clay $(<63 \mu \mathrm{m})$ fraction). In general, no large variations in the environmental parameters measured in the water column have been found, as a result of the estuary hydrological regime. The exceptions were conductivity and total dissolved solids which present a clear distinction between the lower and upper stations. The sedimentological analysis revealed a substratum with coarser sediment with a preponderance of sands (the exceptions were the stations $2,9,10,11$ and 12 with abundant fine matter). The PCA matrices of environmental factors versus sampling stations (Fig. 2) revealed a clear pattern over the estuary. From the projection against the first axis of variability, stations were distributed along a physical and chemical gradient, with the stations with finer sedi- 


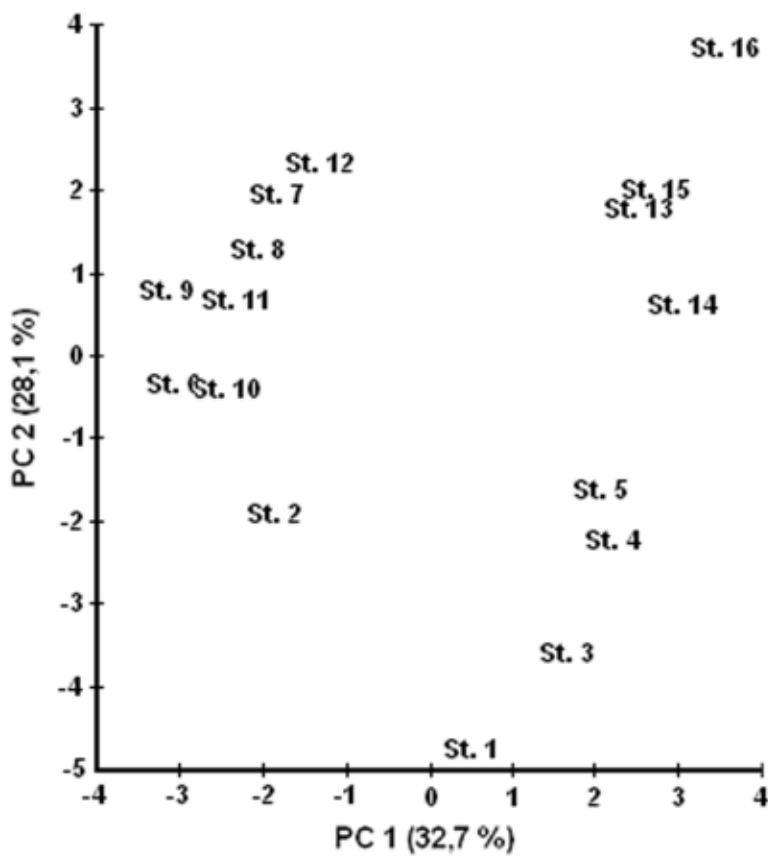

Fig. 2. Analysis of environmental factors of the water column and sediment using Principal Components Analysis (PCA) on environmental factors $\mathrm{x}$ station matrices. The percentage of variability explained by the principal axes is given.

ments along one edge and the stations with coarser sediments located on the other. Along the second axis of variability, the separation of the stations was related to the environmental factors measured in the water column.

Our biological data set consisted of ten molluscan species, namely: Ancylus fluviatilis (Müller, 1774), Anodonta cygnea (Linnaeus, 1758), Bithynia tentaculata (Linnaeus, 1758), Corbicula fluminea (Müller, 1774), Limnaea sp., Physa acuta (Draparnaud, 1805), Pisidium amnicum (Müller, 1774), Potamopyrgus anti- podarum (Gray, 1843), Unio pictorum (Linnaeus, 1758) and Valvata piscinalis (Müller, 1774).

Abundance, biomass and diversity have significant variations along the sixteen sampling stations. Abundance per station ranged from 230 individuals $\mathrm{m}^{-2}$ in station 14 to 4130 individuals $\mathrm{m}^{-2}$ in station 1 with an average of 1412 individuals $\mathrm{m}^{-2}$ (Table 2). C. fluminea was the species with higher densities, which corresponded to $88.7 \%$ of the total number of individuals gathered, and was present in the sixteen sampling stations. $P$. amnicum was the second most abundant species with $5.8 \%$ of total densities. The biomass ranged from $17.0 \mathrm{~g} \mathrm{AFDW} \mathrm{m}^{-2}$ in station 4 to $249.6 \mathrm{~g} \mathrm{AFDW}^{-1}$ $\mathrm{m}^{-2}$ in station 1 with an average of $99.8 \mathrm{~g} \mathrm{AFDW} \mathrm{m}^{-2}$ (Table 3). C. fluminea was the species that clearly dominated with $95.4 \%$ of the total biomass, followed by B. tentaculata with $1.6 \%$. The number of species also had a considerable spatial variation. The maximum value of nine species was registered in station 10 and the minimum, with only one species, in stations $1,2,3,4$, 5, 6, 14, 15 and 16.

The two-dimensional MDS plot of samples based on abundance is shown in Figure 3. Essentially, the biological community of the River Minho estuary includes two groups. These faunal groups are well separated in the MDS ordering, are distinct (the stress level is very low) and are formed by more diverse assemblages in stations 9, 10, 11 and 12 and assemblages almost or exclusively represented by $C$. fluminea in the other sampling stations.

\section{Discussion}

The molluscan fauna occurring in the freshwater tidal area of the River Minho estuary was dominated by the invasive Asiatic clam - $C$. fluminea. The identification of different species within the genus Corbicula was always very complicated due to their marked variation in shell morphology, colour, sculpture and re-

Table 2. Species abundances (individuals $\mathrm{m}^{-2}$ ) at the sixteen sampling stations ( $\mathrm{x}-$ absent).

\begin{tabular}{|c|c|c|c|c|c|c|c|c|c|c|c|c|c|c|c|c|}
\hline Taxa & St. 1 & St. 2 & St. 3 & St. 4 & St. 5 & St. 6 & St. 7 & St. 8 & St. 9 & St. 10 & St. 11 & St. 12 & St. 13 & St. 14 & St. 15 & St. 16 \\
\hline Ancylus fluviatilis (Müller, 1774) & $x$ & $x$ & $x$ & $x$ & $x$ & $x$ & $x$ & $x$ & 10 & $x$ & $x$ & $x$ & $x$ & $x$ & $x$ & $x$ \\
\hline Anodonta cygnea (Linnaeus, 1758) & $x$ & $\mathrm{x}$ & $x$ & $x$ & $\mathrm{x}$ & $x$ & $\mathrm{x}$ & $x$ & $x$ & 10 & $x$ & $\mathrm{x}$ & $x$ & $\mathrm{x}$ & $x$ & $x$ \\
\hline Bithynia tentaculata (Linnaeus, 1758) & $\mathrm{x}$ & $x$ & $\mathrm{x}$ & $x$ & $\mathrm{x}$ & $x$ & $x$ & $x$ & 20 & 60 & 80 & 450 & 10 & $\mathrm{x}$ & $x$ & $x$ \\
\hline Corbicula fluminea (Müller, 1774) & 4130 & 1400 & 1630 & 550 & 1760 & 690 & 460 & 1440 & 1160 & 80 & 380 & 1880 & 2560 & 230 & 1160 & 530 \\
\hline Limnaea sp. & $x$ & $x$ & $x$ & $x$ & $x$ & $x$ & $x$ & $x$ & 10 & 10 & 80 & 20 & $x$ & $\mathrm{x}$ & $x$ & $x$ \\
\hline Physa acufa (Draparnaud, 1805) & $x$ & $x$ & $x$ & $x$ & $x$ & $x$ & $\mathrm{x}$ & $x$ & 10 & 20 & $x$ & 10 & $x$ & $\mathrm{x}$ & $\mathrm{x}$ & $x$ \\
\hline Pisidium amnicum (Müller, 1774) & $x$ & $\mathrm{x}$ & $\mathrm{x}$ & $\mathrm{x}$ & $\mathrm{x}$ & $x$ & $\mathrm{x}$ & $x$ & 30 & 60 & 460 & 750 & 20 & $x$ & $\mathrm{x}$ & $x$ \\
\hline Potamopyrgus antipodarum (Gray, 1843) & $x$ & $x$ & $x$ & $x$ & $\mathrm{x}$ & $x$ & 20 & 40 & 60 & 80 & 20 & 30 & $x$ & $\mathrm{x}$ & $\mathrm{x}$ & $x$ \\
\hline Unio pictorum (Linnaeus, 1758) & $x$ & $x$ & $\mathrm{x}$ & $\mathrm{x}$ & $\mathrm{x}$ & $x$ & $\mathrm{x}$ & $x$ & $\mathrm{x}$ & 20 & $x$ & 10 & $x$ & $\mathrm{x}$ & $x$ & $x$ \\
\hline Valvata piscinalis (Müller, 1774) & $x$ & $x$ & $\mathrm{x}$ & $\mathrm{x}$ & $x$ & $x$ & $x$ & $x$ & $x$ & 90 & 30 & 30 & $x$ & $\mathrm{x}$ & $x$ & $x$ \\
\hline Total & 4130 & 1400 & 1630 & 550 & 1760 & 690 & 480 & 1480 & 1300 & 430 & 1050 & 3180 & 2590 & 230 & 1160 & 530 \\
\hline
\end{tabular}




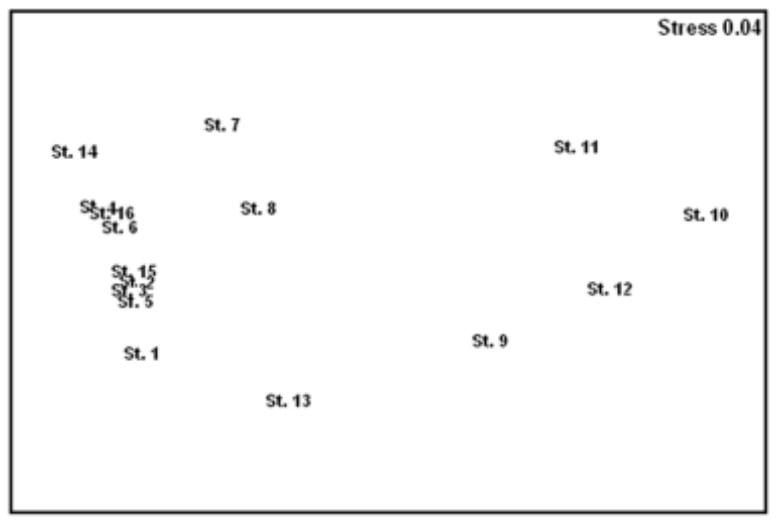

Fig. 3. MDS plot of Molluscan faunal similarity among the sixteen sampling stations present in the freshwater tidal area of River Minho estuary.

productive biology (Rajagopal et al. 2000, Renard et al. 2000, Siripattrawan et al. 2000, Pfenninger et al. 2002). In this work, all the specimens found in the River Minho estuary were considered as $C$. fluminea in agreement with Park \& Kim (2003) who classified the specimens found on this estuary as $C$. fluminea sensu Park et al.(2000), based on COI genotype sequences. This species was firstly recorded in 1989 with nine juveniles (Araujo et al. 1993) and nowadays is a major benthic component in the limnetic area of this estuary with a clear dominance in the total benthic densities and biomass. This species was found in all sampling stations, and in the lower (stations 1, 2, 3, 4, 5, and 6) and upper stations (stations 14, 15 and 16) was the only benthic species - the exceptions were stations 1 and 2 with a presence of few specimens of Hediste diversicolor (Müller, 1776) and Cyathura carinata (Kroyer, 1847). Only stations 9, 10, 11 and 12 have a more diverse molluscan fauna, and showed the presence of oligochaetes (with great densities but low biomass) and insect species. Possible explanations for the great diversities in sampling stations 9, 10, 11 and 12, com- pared to the others sampling stations, were the type of sediment available (fine sediments) with great abundance of organic matter and the presence of submersed macrophytes (Sousa, pers. com.) favourable to the colonization of a more diverse molluscan fauna. In fact, the presence of aquatic submersed vegetation is a very important environmental factor for the spatial distribution of freshwater molluscs, offering these areas a more stable habitat with continuous availability of food, sediment stability, water transparency and protection against predators (Costil \& Clement 1996, Watson \& Ormerod $2004 \mathrm{a}, \mathrm{b})$. The others sampling stations were characterized by habitats with clean, coarse sand (the exception was station 2 with fine sediments) without vegetation cover. This kind of habitats resulted in a lower benthic diversity (Marchand \& Gascuel 1988).

In 1990 the molluscan fauna of the freshwater tidal area of the River Minho estuary included Unionoidea species, such as Anodonta anatina (Linnaeus, 1758), Anodonta cygnea (Linnaeus, 1758), Potomida littoralis (Cuvier, 1798) and Unio pictorum (Linnaeus, 1758); Veneroida order, such as Corbicula fluminea (Müller, 1774), Musculium lacustre (Müller, 1774), Pisidium amnicum (Müller, 1774) and Pisidium henslowanum (Sheppard, 1823), and Gastropoda species such as Ancylus fluviatilis (Müller, 1774), Bithynia tentaculata (Linnaeus, 1758), Gyraulus sp., Hippeutis complanatus (Linnaeus, 1758), Lymnaea sp., Physa acuta (Draparnaud, 1805), Potamopyrgus antipodarum (Gray, 1843) and Valvata piscinalis (Müller, 1774) (Maze et al. 1993, Araujo et al. 1993, 1999, Rolán 1998). In comparison with these results, our study reveals an impoverished molluscan fauna, principally for bivalve species. The native bivalve fauna has nearly disappeared from the River Minho estuary. The exceptions were the upper estuarine areas with residual populations of A. cygnea (only gathered in station 10) and $U$. pictorum (only gathered in stations 10 and 12) and the presence of $P$. amnicum with low densities,

Table 3. Species biomasses $\left(\mathrm{g} \mathrm{AFDWm}^{-2}\right)$ at the sixteen sampling stations ( $\mathrm{x}-$ absent $)$.

\begin{tabular}{|c|c|c|c|c|c|c|c|c|c|c|c|c|c|c|c|c|}
\hline Taxa & St. 1 & St. 2 & St. 3 & St. 4 & St. 5 & St. 6 & St. 7 & St. 8 & St. 9 & St. 10 & St. 11 & St. 12 & St. 13 & St. 14 & St. 15 & St. 16 \\
\hline Ancylus fluviatilis (Müller, 1774) & $x$ & $x$ & $x$ & $\mathrm{x}$ & $x$ & $x$ & $x$ & $\mathrm{x}$ & 0.21 & $x$ & $\mathrm{x}$ & $x$ & $\mathrm{x}$ & $\mathrm{x}$ & $\mathrm{x}$ & $x$ \\
\hline Anodonta cygnea (Linnaeus. 1758) & $x$ & $x$ & $x$ & $x$ & $x$ & $x$ & $\mathrm{x}$ & $x$ & $\mathrm{x}$ & 10.83 & $x$ & $x$ & $\mathrm{x}$ & $\mathrm{x}$ & $x$ & $x$ \\
\hline Bithynia tentaculata (Linnaeus. 1758) & $x$ & $x$ & $x$ & $\mathrm{x}$ & $x$ & $x$ & $x$ & $\mathrm{x}$ & 0.21 & 0.64 & 3.86 & 19.75 & 0.56 & $\mathrm{x}$ & $x$ & $x$ \\
\hline Corbicula fluminea (Müller. 1774) & 249.62 & 96.07 & 70.71 & 16.96 & 59.32 & 93.41 & 32.90 & 106.12 & 198.45 & 8.53 & 32.47 & 182.62 & 121.42 & 19.79 & 72.98 & 162.21 \\
\hline Limnaea sp. & $x$ & $x$ & $x$ & $\mathrm{x}$ & $x$ & $x$ & $\mathrm{x}$ & $\mathrm{x}$ & 0.24 & 0.25 & 1.75 & 0.45 & $\mathrm{x}$ & $x$ & $\mathrm{x}$ & $\mathrm{x}$ \\
\hline Physa acuta (Draparnaud. 1805) & $x$ & $x$ & $x$ & $\mathrm{x}$ & $\mathrm{x}$ & $\mathrm{x}$ & $\mathrm{x}$ & $x$ & 0.05 & 0.10 & $\mathrm{x}$ & 0.06 & $\mathrm{x}$ & $\mathrm{x}$ & $x$ & $x$ \\
\hline Pisidium amnicum (Müller. 1774) & $x$ & $x$ & $x$ & $\mathrm{x}$ & $x$ & $x$ & $x$ & $\mathrm{x}$ & 0.32 & 0.61 & 4.14 & 7.42 & 0.24 & $\mathrm{x}$ & $x$ & $x$ \\
\hline Potamopyrgus antipodarum (Gray. 1843) & $x$ & $x$ & $x$ & $x$ & $x$ & $x$ & 0.01 & 0.02 & 0.03 & 0.04 & 0.01 & 0.02 & $\mathrm{x}$ & $\mathrm{x}$ & $x$ & $\mathrm{x}$ \\
\hline Unio pictorum (Linnaeus. 1758) & $x$ & $\mathrm{x}$ & $x$ & $\mathrm{x}$ & $x$ & $x$ & $\mathrm{x}$ & $\mathrm{x}$ & $\mathrm{x}$ & 13.42 & $x$ & 7.21 & $\mathrm{x}$ & $\mathrm{x}$ & $x$ & $x$ \\
\hline Valvata piscinalis (Müller. 1774) & $x$ & $x$ & $x$ & $x$ & $x$ & $x$ & $\mathrm{x}$ & $\mathrm{x}$ & $x$ & 0.53 & 0.17 & 0.19 & $\mathrm{x}$ & $\mathrm{x}$ & $x$ & $x$ \\
\hline Total & 249.62 & 96.07 & 70.71 & 16.96 & 59.32 & 93.41 & 32.91 & 106.14 & 199.51 & 34.96 & 42.39 & 217.71 & 122.22 & 19.79 & 72.98 & 162.21 \\
\hline
\end{tabular}


compared to the results obtained by Araujo et al. (1999). However, during this study, only random soft bottom samples were taken, which may introduce some bias because mollusc populations, principally gastropods, can be very patchy distributed (Bruyndoncx et al. 2002). Future research may include habitats not surveyed in this study such as the tidal freshwater marshes, rocky substrates and soft bottoms with coarser deposits (e. g. gravels) which may increase the molluscan diversities and could change the abundances and biomass gathered.

The impoverishment of the molluscan fauna (predominantly bivalve species) in some American and European freshwater ecosystems has been speculated to deal with the invasion of $C$. fluminea (Araujo et al. 1993, Williams et al. 1993, Strayer 1999, Aldridge \& Müller 2001). According to Araujo et al. (1993), in large areas of Minho estuary, the colonization and posterior dispersion of $C$. fluminea possibly reduced the populations of the native bivalve $P$. amnicum. This possibility has been related to $C$. fluminea ecological potential to compete with sphaeriids and juvenile unionids for benthic food resources and available habitat (McMahon 1991, Yeager et al. 1994). Behind repercussions in the native populations, species belonging to the Corbicula genus can alter the nature of the food web, the nutrient cycling and quantity of dissolved organic carbon (Yamamuro \& Koike 1993, 1994, Gerritsen et al. 1994, Phelps 1994, Hakenkamp \& Palmer 1999, Strayer et al. 1999, Nakamura \& Kerciku 2000, Kohata et al. 2003).

In summary, the molluscan fauna of the limnetic area of the River Minho estuary seems to be impoverished when compared with anterior studies. The preliminary results that were obtained in this study provide an ecological signal and future resolutions have to be planned in order to stop this general decreasing diversity. The major preoccupation is the ecological condition of the native bivalve species and further research will be necessary to understand the factors responsible for the decreasing abundance, biomass and diversity in this limnetic estuarine area. C. fluminea is a potential key species in the functioning of this estuarine ecosystem and possible ecological impacts will require futher investigation.

\section{Acknowledgements}

Ronaldo Sousa is recipient of a PhD grant from Portuguese Foundation for Science and Technology - FCT (SFRH/BD/18426/2004) and this work was partially funded by FCT (project RISKA). Special thanks are addressed to Eduardo, Gonçalves, Hugo and Fernanda Santos.

\section{References}

Aldridge D.C. \& Müller S.J. 2001. - The Asiatic clam, Corbicula fluminea, in Britain : current status and potential impacts. $J$. Conchol., 37, 177-183.

Alves A.M. 1996. - Causas e processos da dinâmica sedimentar na evolução actual do litoral do Alto Minho. Ph.D. thesis, University of Minho, Portugal, $442 \mathrm{p}$.

Araujo R., Moreno D. \& Ramos M.A. 1993. - The asiatic clam Corbicula fluminea (Müller, 1774) (Bivalvia: Corbiculidae) in Europe. Am. Malacol. Bull., 10, 39-49.

Araujo R., Ramos M.A. \& Molinet R. 1999. - Growth pattern and dynamics of a southern peripheral population of Pisidium amnicum (Müller, 1774) (Bivalvia : Sphaeriidae) in Spain. Malacologia, 41, 119-137.

Attrill M.J., Rundle S.D. \& Thomas R.M. 1996. - The influence of drought-induced low freshwater flow on an upper-estuarine macroinvertebrate community. Wat. Res., 30, 261-268.

Attrill M.J. \& Rundle S.D. 2002. - Ecotone or ecocline: ecological boundaries in estuaries. Estuar. Coast. Shelf S., 55, 929-936.

Bruyndoncx L., Jordaens K., Ysebaert T., Meire P. \& Backeljau T. 2002. - Molluscan diversity in tidal marshes along the Scheldt estuary (The Netherlands, Belgium). Hydrobiologia, 474, 189-196.

Clarke K.R. \& Warwick R.M. 2001. - Change in Marine Communities : an approach to statistical analysis and interpretation, $2^{\text {nd }}$ edition. PRIMER-E Ltd, Plymouth Marine Laboratory, Plymouth.

Costil K. \& Clement B. 1996. - Relationship between freshwater gastropods and plant communities reflecting various trophic levels. Hydrobiologia, 321, 7-16.

Gangnery A., Bacher C. \& Buestel D. 2001. - Assessing the production and the impact of cultivated oysters in the Thau lagoon (Mediterranee, France) with a population dynamic model. Can. J. Fish. Aquat. Sci., 88, 1012-1020.

Gerritsen J., Holand A. F. \& Irvine D.E. 1994. - Suspension-feeding bivalves and the fate of primary production: an estuarine model applied to Chesapeake Bay. Estuaries, 17, 403-416.

Hakenkamp C.C. \& Palmer M.A. 1999. - Introduced bivalves in freshwater ecosystems : the impact of Corbicula on organic matter dynamics in a sandy stream. Oecologia, 119, 445-451.

Kohata K., Hiwatari T. \& Hagiwara T. 2003. - Natural water-purification system observed in a shallow coastal lagoon : Matsukawaura, Japan. Mar. Pollut. Bull., 47, 148-154.

Kramer K.J.M., Brockmann U.H. \& Warwick R.M. 1994. - Tidal estuaries. Manual of sampling and analytical procedure, A. A. Balkema, Rotterdham.

Marchand J. \& Gascuel D. 1988. - Seasonal dynamics of the zoobenthic communities in the mesohaline zone of the Loire estuary (France). Hydrobiologia, 160, 129-139.

Maze R.A., Lastra M. \& Mora J. 1993. - Macrozoobentos del estuario del Miño (NO de España). Publ. Espec. Inst. Esp. Oceanogr., $11,283-290$.

McMahon R.F. 1991. - Mollusca : bivalvia. Pages 315-390 in Ecology and classification of North American freshwater invertebrates. Thorp J.H. \& Covish A.P. (eds). Academic Press, New York.

Nakamura Y. \& Kerciku F. 2000. - Effects of filter-feeding bivalve on the distribution of water quality and nutrient cycling in a eutrophic coastal lagoon. J. Marine Syst., 26, 209-221.

Park G.M., Yong T.S., Im K.I. \& Chung E.Y. 2000. - Karyotypes of three species of Corbicula (Bivalvia : Veneroida) in Korea. $J$. Shellfish. Res., 19, 979-982.

Park J.K. \& Kim W. 2003. - Two Corbicula (Corbiculidae: Bivalvia) mitochondrial lineages are widely distributed in Asian freshwater environment. Mol. Phylogenet. Evol., 29, 529-539.

Pfenninger M., Reinhardt F. \& Streit B. 2002. - Evidence for cryptic hybridization between different evolutionary lineages of the inva- 
sive clam genus Corbicula (Veneroida, Bivalvia). J. Evol. Biol., $15,818-829$

Phelps H.L. 1994. - The Asiatic clam (Corbicula fluminea) invasion and System-Level Ecological Change in the Potomac River Estuary near Washington, D. C. Estuaries, 17, 614-621.

Rajagopal S., van der Velde G. \& bij de Vaate A. 2000. - Reproductive biology of the Asiatic clams Corbicula fluminalis and Corbicula fluminea in the river Rhine. Arch. Hydrobiol., 149, 403420.

Rolán E. 1998. - Evolución de la situación actual de las especies de moluscos de agua dulce existentes en el tramo del Río Miño de Goián-Eiras (Galicia, NO España). Thalassas, 14, 99-103.

Renard E., Bachmann V., Cariou M.L. \& Moreteau J.C. 2000. - Morphological and molecular differentiation of invasive freshwater species of the genus Corbicula (Bivalvia, Corbiculidea) suggest the presence of three taxa in French rivers. Mol. Ecol., 9, 20092016.

Rundle S.D., Attrill M.J. \& Arshad A. 1998. - Seasonality in macroinvertebrates community composition across a neglected ecological boundary, the freshwater-estuarine transition zone. Aquat. Ecol., 32, 211-216.

Schiemer F. \& Zalewski M. 1992. - The importance of riparian ecotones for diversity and productivity of riverine fish communities. Neth. J. Zool., 42, 323-335.

Siripattrawan S., Park J.K. \& O' Foighil D. 2000. - Two lineages of the introduced Asian freshwater clam Corbicula occur in North America. J. Moll. Stud., 66, 423-429.

Strayer D.L. 1999. - Effects of alien species on freshwater molluscs in North America. J. N. Am. Benthol. Soc., 18, 74-98.

Watson A.M. \& Ormerod S.J. 2004a. - The microdistribution of three uncommon freshwater gastropods in the drainage ditches of
British grazing marshes. Aquat. Conserv. : Mar. Freshw. Ecosyst., 14, 221-236.

Watson A.M. \& Ormerod S.J. 2004b. - The distribution of three uncommon freshwater gastropods in the drainage ditches of British grazing marshes. Biol. Conserv., 118, 455-466.

Williams A.C., Warren M.L., Cumming K.S., Harris J.L. \& Neves R.J. 1993. - Conservation status of freshwater mussels of the United States and Canada. Fisheries, 18, 6-22.

Yamamuro M. \& Koike I. 1993. - Nitrogen metabolism of the filterfeeding bivalve Corbicula japonica and its significance in primary production of a brackish lake in Japan. Limnol. Oceanogr., 38, 997-1007.

Yamamuro M. \& Koike I. 1994. - Diel changes of nitrogen species in surface and overlying water of an estuarine lake in summer: evidence for benthic-pelagic coupling. Limnol. Oceanogr., 39, 1726-1733.

Yeager M.M., Cherry D.S. \& Neves R.J. 1994. - Feeding and burrowing behaviours of juvenile rainbow mussels Villoa iris (Bivalvia : Unionidae). J. N. Am. Benthol. Soc., 13, 217-222.

Ysebaert T., Meire P., Coosen J. \& Essink K. 1998. - Zonation of intertidal macrobenthos in the estuaries of Schelde and Ems. Aquat. Ecol., 32, 53-71.

Ysebaert T., Meire P., Herman P. M. J. \& Verbeek H., 2002. - Macrobenthic species response surfaces along estuarine gradients: prediction by logistic regression. Mar. Ecol. Prog. Ser., 225, 7995.

Ysebaert T., Herman P.M J., Meire P., Craeymeersch J., Verbeek H. \& Heip C.H.R. 2003. - Large-scale spatial patterns in estuaries: estuarine macrobenthic communities in the Schelde estuary, NW Europe. Estuar. Coast. Shelf S., 57, 335-355. 